archives-ouvertes

\title{
Bioorganic Farming Practices as a Source of Atypical Ectoparasitosis
}

Guan Zhu, Olaf Kniemeyer, Neta Shlezinger, Amariliz Rivera, Moreira Gmsg, Sanz Ab, David Chauvin, Michael Hust, Mark Schütte, Adélaïde Chesnay, et al.

\section{To cite this version:}

Guan Zhu, Olaf Kniemeyer, Neta Shlezinger, Amariliz Rivera, Moreira Gmsg, et al.. Bioorganic Farming Practices as a Source of Atypical Ectoparasitosis. Archives of Dermatology -Chicago-, American Medical Association, 2011. hal-02443816

\section{HAL Id: hal-02443816 https://hal.archives-ouvertes.fr/hal-02443816}

Submitted on 17 Jan 2020

HAL is a multi-disciplinary open access archive for the deposit and dissemination of scientific research documents, whether they are published or not. The documents may come from teaching and research institutions in France or abroad, or from public or private research centers.
L'archive ouverte pluridisciplinaire HAL, est destinée au dépôt et à la diffusion de documents scientifiques de niveau recherche, publiés ou non, émanant des établissements d'enseignement et de recherche français ou étrangers, des laboratoires publics ou privés. 


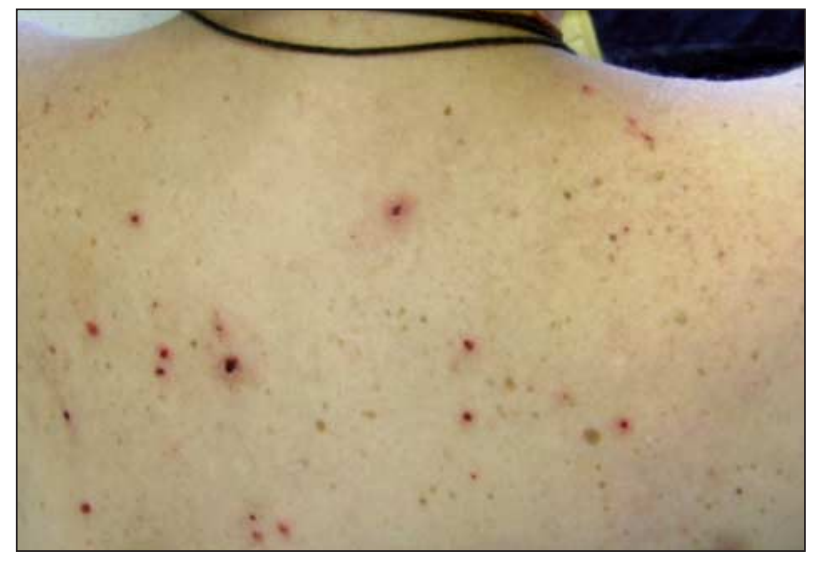

Figure 1. Dermatitis of the nape and the top of the back. Note the bloody crusty aspect of the lesions due to intense itching.

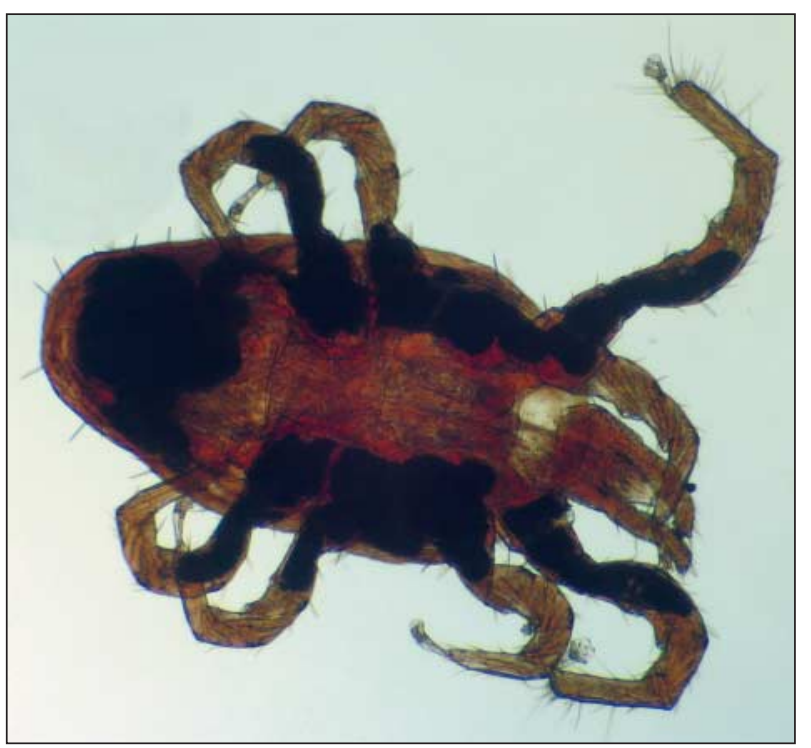

Figure 2. Acarine subject Dermanyssus gallinae. The flattened hairy body is elliptical, not segmented. Four pairs of long legs are all inserted in the anterior part. At the extremity of each leg, 2 claws are arranged in pliers. At the apical part, 2 threadlike chelicerae surround the mouth. There is no antenna. A red/brown color was noticeable, perhaps because of the presence of a blood meal.

nests. Currently, bioorganic products restrict insecticide treatments, which allows transmission of atypical ectoparasitosis to people.

Cases of human infestation with Dermanyssus species are uncommon. Patients feel painful localized bites with constant pruritus and urticarious maculopapular eruptions. Excoriated lesions and crusted ulcers may appear. Because clinical manifestations mirror those of scabies or pediculosis, diagnosis is often difficult; therefore, products usually active against lice and sarcoptic mites may be used ineffectively on human infestation with Dermanyssus species.

The source of contamination must be identified and eradicated. Patients should be kept away from the acarine repository and permitted to heal spontaneously. When the present patient stopped her daily egg collection in the henhouse, the pruritus progressively decreased. Treatment with high-dose oral antiparasitic has been tried with limited success. ${ }^{4}$ Concomitantly, inshe maintained a henhouse in her backyard and leaned
into the henhouse to harvest fresh eggs from the laying 
fested locations should be thoroughly coated with pyrethrin sprays. Bedding and clothes need to be washed at high temperatures. Resistance toward traditional acaricides are emerging in the poultry-breeding industry. In the near future, it could become an environmental problem. ${ }^{5}$

Guillaume Desoubeaux, PharmD, PhD Marlène Amara, PharmD

Julien Goustille, PharmD

Jacques Chandenier, $M D, P h D$

Author Affiliations: Unit of Parasitology-MycologyTropical Medicine, University Hospital Bretonneau, Tours, France (Drs Desoubeaux, Amara, and Chandenier); Service of Medical Biology, General Hospital of St Malo, St Malo, France (Dr Goustille).

Correspondence: Dr Desoubeaux, Unit of ParasitologyMycology-Tropical Medicine, University Hospital Bretonneau, 2 Blvd Tonnellé, Bâtiment B2A, 37044 Tours, Cedex 09, France (guillaume.desoubeaux@univ-tours .fr).

Financial Disclosure: None reported.

Additional Contributions: We are indebted to Pierre Domart, MD, dermatologist in Blois, France.

1. Roy L, Chauve CM. Historical review of the genus Dermanyssus Dugès, 1834 (Acari: Mesostigmata: Dermanyssidae). Parasite. 2007;14(2):87-100.

2. Haag-Wackernagel D, Bircher AJ. Ectoparasites from feral pigeons affecting humans. Dermatology. 2010;220(1):82-92.

3. Bellanger AP, Bories C, Foulet F, Bretagne S, Botterel F. Nosocomial dermatitis caused by Dermanyssus gallinae. Infect Control Hosp Epidemiol. 2008; 29(3):282-283.

4. Ash LS, Oliver JH Jr. Susceptibility of Ornithodoros parkeri (Cooley) (Acari: Argasidae) and Dermanyssus gallinae (DeGeer) (Acari: Dermanyssidae) to ivermectin. J Med Entomol. 1989;26(3):133-139.

5. Beugnet F, Chauve C, Gauthey M, Beert L. Resistance of the red poultry mite to pyrethroids in France. Vet Rec. 1997;140(22):577-579. 